\title{
Students' Critical Thinking Ability on Solving 6th Grade Mathematical Problems at SD Hang Tuah 10 Juanda
}

\author{
Pingki Maulidta Sari ${ }^{1 *}$, Ida Sulistyawati ${ }^{2}$, Via Yustitia ${ }^{3}$ \\ 1, 2,3 Universitas PGRI Adi Buana Surabaya \\ *maulidtasaripingki19@gmail.com
}

Received: April 2021. Accepted: May 2021. Published: July 2021.

\begin{abstract}
Students' critical thinking ability in solving FPB and KPK material stories in grade IV is relatively low. The lack of critical thinking ability of these students is because students are not familiar with the question that refers to the level of critical thinking. So that students' critical thinking skills become uneceptible. The purpose of this study is to find out the critical thinking ability of students in working on FPB and KPK stories. This research uses descriptive qualitative research. The subject of this study was IVC grade students at SD Hang Tuah 10 Juanda as many as 6 students. The technique used is purposive sampling by using data collection method in the form of tests as many as 4 description questions. The results of this study showed that students have not been able to identify information from problems based on story problems, students have not been able to formulate or determine the subject matter, some students are able to solve problems with a variety of alternative solutions correctly, there are also some students who are able to solve problems but with incorrect calculations, and most students have not been able to draw clear conclusions for all problems, and only a small percentage of students are able to draw conclusions correctly. Students find it difficult to work on the problem because they do not understand the concept. Keywords: critical thinking, a matter of story, FPB and KPK
\end{abstract}

How to Cite: Sari, P. M., Sulistyawati, I., \& Yustitia, V. (2021). Students' Critical Thinking Ability on Solving 6th Grade Mathematical Problems at SD Hang Tuah 10 Juanda. Journal of Medives: Journal of Mathematics Education IKIP Veteran Semarang, 5(2), 223-233. 


\section{PENDAHULUAN}

Pembelajaran abad 21 merupakan pembelajaran dengan menginterpretasikan 4 keterampilan yang dikenal dengan istilah 4C yaitu, keterampilan berpikir kritis (critical thinking), keterampilan berpikir kreatif (creativity), keterampilan bekerja sama atau berkolaborasi (collaboration), dan keterampilan berkomunikasi (communication). Pembelajaran berpikir kritis merupakan salah satu keterampilan dalam pembelajaran abad 21 yang sangat penting dikuasai oleh siswa untuk melatih siswa dalam menyelesaikan permasalahan yang tidak hanya berhubungan dengan pembelajaran di sekolah, melainkan juga permasalahan dalam kehidupan sehari-hari siswa (Astiar \& Satianingsih, 2020). Menurut Wechsler (2018), berpikir kritis merupakan sebuah proses yang melibatkan penalaran dan analisis untuk menghasilkan suatu kesimpulan. Dengan adanya kemampuan tersebut siswa mampu menyusun argumen ataupun membuat keputusan. Salah satu muatan pelajaran yang mampu mengasah kemampuan berpikir kritis siswa yaitu matematika.

Matematika merupakan ilmu dasar yang banyak kita jumpai di kehidupan sehari-hari yang mampu mengembangkan kemampuan siswa dalam hal berpikir nalar, logis, sistematis, dan kritis (Pradana, 2019). Misalnya dalam pembuatan baju, transaksi perdagangan, pertukangan, dan lain-lain. Bagi beberapa orang menganggap bahwa matematika merupakan ilmu yang sulit untuk dipelajari dan ada juga yang menganggap matematika merupakan ilmu yang mudah dan menyenangkan.
Dengan membentuk kemampuan berpikir kritis, siswa diharapkan mampu mengasah cara berpikirnya dalam hal analisis, berpikir secara rasional, terlatih dalam mengambil keputusan, dan lainlain (Kusmaharti, 2020). Namun, pada kenyataannya pembelajaran matematika yang berlangsung pada saat ini khususnya pada materi FPB dan KPK. Pada dasarnya guru berperan sebagai fasilitator dalam proses pembelajaran dan menghidupkan suasana kelas menjadi menyenangkan atau dalam proses pembelajaran tersebut siswa menjadi tidak pasif (Hwa, 2018). Siswa yang pasif disebabkan adanya beberapa kemungkinan yaitu, ketidakpahaman materi yang sedang diajarkan, takut untuk bertanya, dan juga metode pembelajaran yang terpusat oleh guru. Sehingga siswa hanya menyimak penjelasan dari guru dalam memberikan cara-cara penyelesaian dalam contoh soal.

Hal tersebut, membuat siswa cenderung untuk menghafal rumus dan melakukan perhitungan serta langkahlangkah penyelesaian yang sesuai dengan apa yang guru contohkan. Pada umumnya dalam pembuatan soal guru masih berpangku tangan dengan berbagai sumber seperti buku teks yang belum memuat soal-soal yang mengacu kepada kemampuan berpikir kritis siswa. Soal yang berkaitan dengan materi FPB dan KPK adalah soal cerita. Soal cerita merupakan soal yang menyajikan permasalahan dalam kehidupan seharihari dalam bentuk narasi yang terdiri atas beberapa kalimat yang didalam nya terdapat persoalan atau permasalahan yang penyelesaiannya menggunakan keterampilan menghitung. 
Dalam menyelesaikan soal cerita, diperlukan adanya kemampuan berpikir kritis dalam menganalisis soal, mengidentifikasi pertanyaan, dan menentukan penyelesaian dengan benar. Berdasarkan permasalahan tersebut, hal ini dikarenakan pelaksanaan pembelajaran matematika belum sepenuhnya melatih kemampuan berpikir kritis siswa. Sehingga mengakibatkan kurangnya kemampuan berpikir kritis yang dimiliki siswa. Kemampuan berpikir kritis dalam pembelajaran matematika sangat diperlukan guna memahami dan memecahkan suatu permasalahan pada soal matematika yang membutuhkan penalaran, analisis, evaluasi, dan interpretasi pikiran. Berdasarkan latar belakang di atas, peneliti akan menganalisis kemampuan berpikir kritis siswa dalam menyelesaikan soal cerita FPB dan KPK di SD Hang Tuah 10 Juanda.

\section{METODE PENELITIAN}

Jenis penelitian ini menggunakan penelitian deskriptif dengan pendekatan kualitatif. Pada penelitian ini menganalisis kemampuan berpikir kritis siswa dalam menyelesaikan soal cerita FPB dan KPK berdasarkan indikator yang telah disusun. Tujuannya untuk mendeskripsikan kemampuan berpikir kritis siswa dengan menyajikan data tersebut dalam bentuk uraian kata.

Subjek dalam penelitian ini adalah enam dari 24 siswa kelas IVC SD Hang Tuah 10 Juanda dengan metode pengumpulan data berupa tes. Instrumen tes yang digunakan adalah soal uraian matematika yang berorientasi pada kemampuan berpikir kritis.
Dalam suatu penelitian diperlukan instrumen penelitian yang valid. Oleh karena itu, peneliti membuat instrumen penelitian berupa tes uraian yang dibuat oleh peneliti sendiri berdasarkan indikator dan telah divalidasi. Jika instrumen telah valid, maka instrumen tersebut dapat digunakan pada tahap pengumpulan data. Pada tahap ini dilakukan tes berupa 4 soal uraian yang bertaraf berpikir kritis pada materi FPB dan KPK untuk mengetahui kemampuan berpikir kritis siswa.

Setelah tes dilakukan, tahap selanjutnya yaitu analisis data, pada tahap ini data yang telah terkumpul kemudian dianalisis berdasarkan indikator kemampuan berpikir kritis (IKBK) menurut Jacob \& Sam (2008:3), yaitu: (1) klarifikasi, memahami masalah, kemudian menyebutkan semua data yang diketahui dan pokok permasalahan dengan tepat, (2) asesmen, merumuskan informasi dengan cara mengidentifikasi informasi yang relevan dan menemukan pertanyaan-pertanyaan penting dalam masalah, (3) inferensi, membuat kesimpulan berdasarkan informasi yang diperoleh, (4) strategi, berpikir secara terbuka dalam memecahkan masalah dengan cara mengevaluasi langkahlangkah dan hasil pemecahan masalah, menentukan solusi lain dalam pemecahan masalah. Analisis ini bertujuan untuk mendeskripsikan kemampuan berpikir kritis siswa.

Setelah itu, melakukan pengkategorian dari hasil tes siswa. Skor hasil pekerjaan siswa selanjutnya akan dianalisis tiap indikator untuk mengetahui kemampuan berpikir kritis siswa dengan mengacu pada kategori persen- 
tase kemampuan berpikir kritis yang diadaptasi oleh Setyowati dalam penelitian Karim dan Normaya (2015: 96) yang dapat dilihat pada Tabel 1 .

Tabel 1. Kategori Persentase Kemampuan Berpikir Kritis

\begin{tabular}{cc}
\hline Interpretasi $(\%)$ & Kategori \\
\hline $81,25<\mathrm{x}<100$ & Sangat Tinggi \\
$71,5<\mathrm{x}<81,25$ & Tinggi \\
$62,5<\mathrm{x}<71,5$ & Sedang \\
$43,75<\mathrm{x}<62,5$ & Rendah \\
$0<\mathrm{x}<43,75$ & Sangat Rendah \\
\hline
\end{tabular}

Adapun langkah-langkah pengelompokannya sebagai berikut. Pertama, mencari nilai perolehan siswa berdasarkan rubrik penilain. Kedua, nilai tersebut digolongkan ke dalam indikator yang tiap indikator mencakup keempat soal. Ketiga, menentukan persentasenya.

\section{HASIL DAN PEMBAHASAN}

Dari hasil tes kemampuan berpikir kritis dari 6 subjek siswa, akan dilanjutkan pada tabel yang diukur berdasarkan pedoman penskoran kemampuan berpikir kritis siswa. Pedoman penskoran dilakukan per indikator pada masing-masing soal. Terdapat empat soal yang masingmasing indikator memperoleh skor maksimal 5 dan untuk indikator penyelesaian masalah (strategi) diberi skor maksimal 10, jadi total skor per soal adalah 25. Hasil penskoran 6 siswa (subjek) dapat dilihat pada Tabel 2. Kemudian untuk menghitung persentasenya digunakan persamaan berikut.

Nilai persentase $=\frac{\text { Skor Perolehan }}{\text { Skor Maksimal }} \times 100 \%$
Tabel 2. Penskoran Tes Kemampuan

Berpikir Kritis per Indikator

\begin{tabular}{|c|c|c|c|c|c|c|}
\hline \multirow{2}{*}{ No } & \multirow{2}{*}{ Sampel } & \multicolumn{4}{|c|}{ Skor pada Indikator } & \multirow{2}{*}{$\begin{array}{l}\text { Total } \\
\text { Nilai }\end{array}$} \\
\hline & & $(1)$ & $(2)$ & (3) & (4) & \\
\hline 1. & $\mathrm{~S}_{1}$ & 0 & 0 & 28 & 0 & 28 \\
\hline 2. & $\mathrm{~S}_{2}$ & 5 & 0 & 22 & 6 & 33 \\
\hline 3. & $\mathrm{~S}_{3}$ & 0 & 0 & 32 & 11 & 43 \\
\hline 4. & $\mathrm{~S}_{4}$ & 16 & 15 & 28 & 0 & 59 \\
\hline 5. & $\mathrm{~S}_{5}$ & 20 & 20 & 40 & 16 & 96 \\
\hline \multirow[t]{2}{*}{6.} & $\mathrm{~S}_{6}$ & 20 & 20 & 38 & 16 & 94 \\
\hline & Jumlah & 61 & 55 & 188 & 49 & \\
\hline
\end{tabular}

Tabel 3. Persentase Tes Kemampuan Berpikir Kritis

\begin{tabular}{|c|c|c|c|}
\hline No & $\begin{array}{c}\text { Indikator } \\
\text { Kemampuan } \\
\text { Berpikir Kritis }\end{array}$ & $\begin{array}{c}\text { Persentase } \\
(\%)\end{array}$ & Kategori \\
\hline 1. & $\begin{array}{l}\text { Menyebutkan } \\
\text { informasi yang } \\
\text { diketahui } \\
\text { (klarifikasi) }\end{array}$ & 30,5 & $\begin{array}{l}\text { Sangat } \\
\text { Rendah }\end{array}$ \\
\hline 2. & $\begin{array}{l}\text { Merumuskan } \\
\text { pertanyaan } \\
\text { berdasarkan } \\
\text { permasalahan } \\
\text { (asesmen) }\end{array}$ & 27,5 & $\begin{array}{l}\text { Sangat } \\
\text { Rendah }\end{array}$ \\
\hline 3. & $\begin{array}{l}\text { Menyelesaikan } \\
\text { permasalahan } \\
\text { (strategi) }\end{array}$ & 47 & Rendah \\
\hline 4. & $\begin{array}{l}\text { Menarik } \\
\text { kesimpulan } \\
\text { (inferensi) }\end{array}$ & 24,5 & $\begin{array}{l}\text { Sangat } \\
\text { Rendah }\end{array}$ \\
\hline
\end{tabular}

Berdasarkan Tabel 3, dapat diketahui bahwa kemampuan berpikir kritis siswa per indikator termasuk ke dalam dua kategori yaitu rendah dan sangat rendah. Kemampuan berpikir kritis siswa dalam menyebutkan informasi yang diketahui (klarifikasi) termasuk ke dalam kategori sangat rendah, merumuskan pertanyaan berdasarkan permasalahan (asesmen) termasuk ke dalam kategori sangat rendah, serta menyelesaikan permasalahan (strategi) termasuk ke dalam kategori rendah, dan menarik kesimpulan (inferensi) termasuk ke dalam kategori sangat rendah. Hal tersebut sejalan dengan hasil pembahas- 
an dari penelitian Karim dan Normaya (2015) dalam mendeskripsikan kemampuan berpikir kritis yang mana bahwa kemampuan berpikir kritis siswa per indikator tersebar dalam dua kategori, yaitu sangat rendah dan rendah.

Hal yang sama juga dikemukakan oleh Windayana (2007) memperlihatkan bahwa kemampuan berpikir kritis siswa di sekolah dasar masih rendah. Hal ini ditunjukkan dengan rata-rata skor tes siswa yang hanya memperoleh 58,8 . Rendahnya kemampuan berpikir kritis matematis siswa dalam pembelajaran matematika perlu mendapat perhatian serius dari semua kalangan terutama guru matematika. Banyak faktor yang menyebabkan rendahnya kemampuan berpikir siswa dalam proses pembelajaran. Salah satunya adalah pembelajaran yang berpusat pada guru (konvensional) seperti yang sering diterapkan di sekolah-sekolah selama ini, dimana peran guru lebih dominan sehingga siswa cenderung pasif (Ismaimuza, 2010) dan Rusminati \& Sulistyawati (2018).

Berdasarkan hasil penelitian tersebut, siswa menjadi tidak terbiasa dengan adanya penerapan soal yang bertaraf kemampuan berpikir kritis, melainkan hanya sebatas pemahaman yang diajarkan oleh guru. Sehingga siswa tidak dapat mengidentifikasi permasalahan. Siswa langsung membuat alternatif penyelesaian masalah tanpa menganalisis permasalahan dengan baik, siswa langsung terpaku pada hasil akhir dan tidak memperhatikan proses pengerjaannya sehingga menimbulkan pemecahan masalah yang keliru.
Siswa tidak menuliskan unsurunsur yang diketahui dari soal karena merasa tidak perlu. Siswa langsung menjawab pada tahap merencanakan dan menyelesaikan masalah. Sebagian besar siswa yang mengalami kesulitan dalam menyelesaikan soal disebabkan mereka tidak memahami materi atau konsep dari KPK dan FPB. Oleh karena itu semua siswa dalam mengerjakan soal langsung pada tahap penyelesaian masalah atau indikator penyelesaian masalah (strategi). Hal ini sejalan dengan penelitian Mira Azizah et al.(2018) yang menjelaskan bahwa penelitian ini sebagian besar siswa mampu berpikir kritis dalam pembelajaran matematika, namun hasil tersebut hanya didominasi pada indikator tertentu dalam keterampilan berpikir kritis.

Ada beberapa siswa yang masih bingung dalam merencanakan penyelesaian soal, apakah memakai KPK atau FPB. Masih ada siswa yang belum bisa atau lupa bagaimana cara menentukan KPK dan FPB. Sebagian besar siswa tidak memeriksa kembali hasil pekerjaannya dan tidak teliti dalam menyelesaikan soal karena ingin segera mengumpulkan tanpa memeriksa kembali, sehingga terdapat beberapa angka dalam soal yang bukan untuk dicari tetapi justru dicari atau difaktorkan dan juga terdapat hasil pemfaktoran yang kurang tepat. Hal ini sesuai dengan hasil penelitian yang dilakukan oleh Ariani (2018: 33) yang mengatakan bahwa siswa kurang teliti, lupa serta tergesa-gesa dalam mengerjakan soal, sehingga siswa keliru atau tidak sama sekali memeriksa hasil jawaban yang diperoleh. Siswa tidak menyukai 
soal yang berbentuk soal cerita karena dianggap sulit untuk dipahami, sehingga guru pun jarang memberikan soal-soal yang diharuskan untuk berpikir kritis.

Proses berpikir kritis siswa merupakan tahapan-tahapan siswa dalam menentukan hubungan antara informasi tentang suatu masalah dengan pengetahuan yang telah dimiliki siswa. Pada penelitian ini, peneliti akan mengambil 2 subjek siswa yang memiliki kemampuan berpikir kritis sangat rendah $\left(\mathrm{S}_{1}\right)$ dan siswa yang memiliki kemampuan berpikir kritis tinggi $\left(\mathrm{S}_{5}\right)$ guna membahas tentang gambaran proses atau urutan berpikir kritis siswa dalam menyelesaikan soal cerita yang sesuai dengan indikator berpikir kritis. Berikut paparan proses berpikir kritis siswa dalam menyelesaikan soal cerita.

\section{Mengidentifikasi Semua Informasi dari Permasalahan (Klarifikasi)}

Berdasarkan hasil keterampilan berpikir kritis siswa pada Tabel 2, pada indikator mengidentifikasi informasi sebanyak $30,5 \%$ siswa tergolong kategori sangat rendah. Gambar 1 adalah hasil pekerjaan siswa kategori rendah $\left(\mathrm{S}_{1}\right)$.

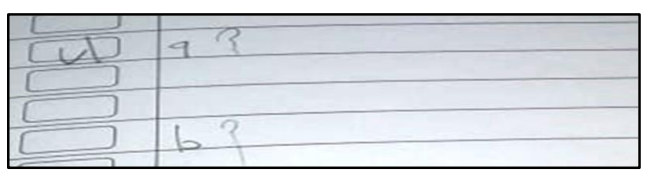

Gambar 1. Hasil Pekerjaan Siswa Kategori Sangat Rendah

Siswa yang dalam kategori sangat rendah berarti siswa tersebut tidak mengerjakan atau tidak bisa membedakan apa yang harus ditulis pada diketahui dan ditanyakan.
Sedangakan siswa yang termasuk ke dalam kategori tinggi sudah memahami soal dan mampu mengidentifikasi informasi berdasarkan permasalahan dan menulis kalimat pertanyaan dengan benar. Gambar 2 adalah hasil pekerjaan siswa kategori tinggi $\left(\mathrm{S}_{5}\right)$.

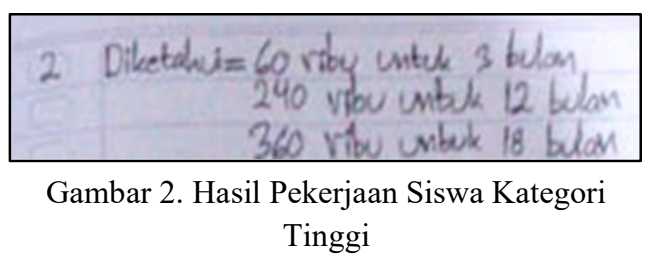

Berdasarkan hal tersebut sejalan dengan hasil pembahasan dari penelitian yang diteliti oleh Yustitia (2017) dan Putra (2018) menyatakan bahwa siswa belum terbiasa mengerjakan soal-soal berpikir kritis sehingga sulit untuk memahami informasi yang ada dalam soal.

\section{Merumuskan Pertanyaan Berdasar- kan Permasalahan (Asesmen)}

Berdasarkan hasil keterampilan berpikir kritis siswa pada Tabel 2, pada indikator mengidentifikasi informasi sebanyak 27,5\% siswa tergolong kategori sangat rendah. Gambar 3 adalah hasil pekerjaan siswa kategori sangat rendah $\left(\mathrm{S}_{1}\right)$.

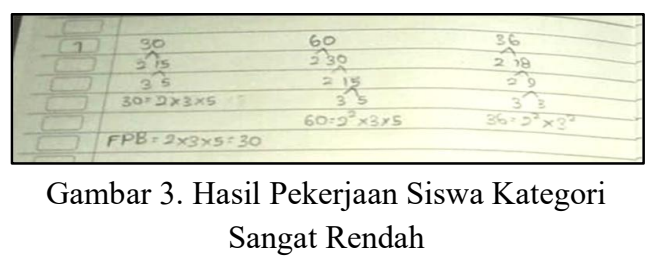

Siswa yang dalam kategori sangat rendah berarti siswa tersebut tidak menuliskan kalimat pertanyaan maupun mengidentifikasi informasi, melainkan pada langsung ke tahap penyelesaian. 
Sedangkan siswa yang termasuk ke dalam kategori tinggi sudah memahami soal dan mampu menulis kalimat pertanyaan dengan benar. Gambar 4 adalah hasil pekerjaan siswa kategori tinggi $\left(\mathrm{S}_{5}\right)$.

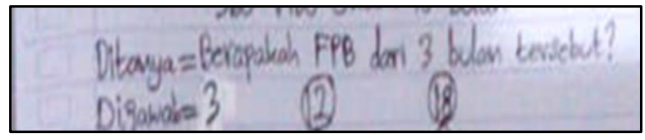

Gambar 4. Hasil Pekerjaan Siswa Kategori Tinggi

O'Sullivan \& Dallas (2010) dalam penelitiannya menyebutkan bahwa kemampuan siswa dalam merumuskan permasalahan sangat efektif karena berkaitan dengan topik permasalahan yang akan diselesaikan, membantu memfokuskan gagasan siswa, dan menuntun pada penelitian yang akan dilakukan. Hal ini dikarenakan siswa belum terbiasa dengan proses penyelesaian soal dengan cara merumuskan pertanyaan terlebih dahulu, sehingga siswa langsung menuju ke tahap penyelesaian.

\section{Menyelesaikan Masalah dengan Beragam Alternatif Penyelesaian Berdasarkan Konsep (Strategi)}

Berdasarkan hasil keterampilan berpikir kritis siswa pada Tabel 2, pada indikator mengidentifikasi informasi $47 \%$ siswa tergolong kategori rendah. Berikut hasil pekerjaan siswa kategori sangat rendah $\left(\mathrm{S}_{1}\right)$.

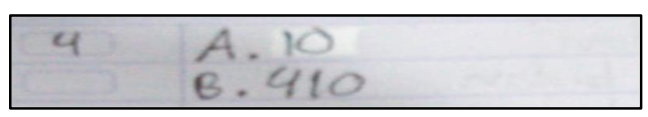

Gambar 5. Hasil Pekerjaan Siswa Kategori Sangat Rendah
Siswa yang dalam kategori sangat rendah berarti siswa tersebut tidak mampu menyelesaikan permasalahan sesuai dengan konsep permasalahan maupun langkah-langkah penyelesaian, melainkan hanya menulis jawaban berupa angka yang tidak tahu dari mana asal angka tersebut.

Sedangkan siswa yang termasuk ke dalam kategori tinggi sudah memahami soal dan mampu menyelesaikan permasalahan dengan konsep dan langkah-langkah penyelesaian yang benar. Gambar 6 adalah hasil pekerjaan siswa kategori tinggi $\left(\mathrm{S}_{5}\right)$.

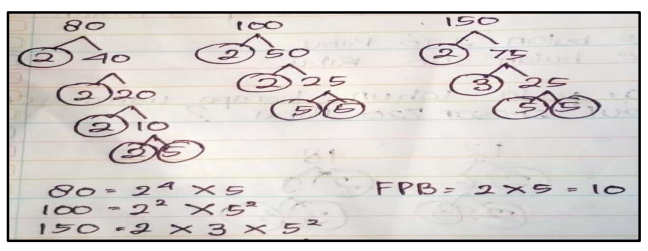

Gambar 6. Hasil Pekerjaan Siswa Kategori Tinggi

Menurut Gilmer (1970) (dalam Kuswana 2011 dan Wardani, 2018), "berpikir merupakan suatu pemecahan masalah dan proses penggunaan gagasan atau lambang-lambang pengganti suatu aktivitas yang tampak secara fisik". Dalam menyelesaikan masalah harus menggunakan suatu aktivitas berpikir, dan dalam menyelesaikannya menggunakan konsep matematika. Indikator penyelesaikan masalah dengan alternatif penyelesaian dalam keterampilan berpikir kritis berarti merencanakan solusi dari permasalahan melalui penerapan konsep-konsep matematika yang telah dimiliki siswa. Indikator ini meliputi kemampuan dalam menulis langkahlangkah pengerjaan secara lengkap dan urut. Pada penelitian ini siswa sudah 
dapat menyelesaikan masalah dengan beragam alternatif penyelesaian. Akan tetapi, masih ada beberapa siswa yang dalam perhitungan masih belum tepat atau kurang teliti, menggunakan konsep matematika yang tidak tepat (tidak dapat membedakan FPB dan KPK), dan ada beberapa siswa yang belum mencapai indikator penyelesaian masalah dengan alternatif penyelesaian (hanya mengerjakan pohon faktor saja) karena belum terbiasa mengerjakan soal yang berorientasi pada kemampuan berpikir kritis.

Berdasarkan temuan tersebut, maka perlu adanya pembiasaan penerapan kemampuan berpikir kritis dalam pembelajaran sebagaimana pendapat Dede Nuraida (2019) dan Yustitia \& Amin (2020) bahwa guru harus mengembangkan strategi pembelajaran yang tepat dengan adanya interaksi diantara siswa guna mendorong kemampuan berpikir kritis.

\section{Menarik Kesimpulan (Inferensi)}

Berdasarkan hasil keterampilan berpikir kritis siswa pada Tabel 2, pada indikator mengidentifikasi informasi sebanyak 24,5\% siswa tergolong kategori sangat rendah. Gambar 7 adalah hasil pekerjaan siswa kategori sangat rendah $\left(\mathrm{S}_{1}\right)$.

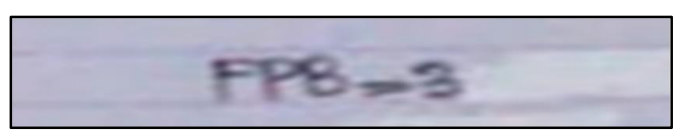

Gambar 7. Hasil Pekerjaan Siswa Kategori Sangat Rendah

Siswa yang dalam kategori sangat rendah berarti siswa tersebut tidak mampu menyimpulkan hasil dari tahap penyelesaian masalah, melainkan hanya menuliskan angka yang telah didapat dari hasil perhitungan tanpa menyimpulkan kembali pertanyaan yang dicari dalam soal cerita.

Sedangkan siswa yang termasuk ke dalam kategori tinggi mampu membuat kesimpulan berdasarkan permasalahan dengan baik dan benar. Gambar 8 adalah hasil pekerjaan siswa kategori tinggi $\left(\mathrm{S}_{5}\right)$.

$$
\begin{gathered}
\text { Jadl' woumlah warga yang paling } \\
\text { patuak tersanglat covid 10, Orang } \\
\text { Gambar 8. Hasil Pekerjaan Siswa Kategori } \\
\text { Tinggi }
\end{gathered}
$$

Berpikir kritis dapat didefinisikan sebagai kemampuan membuat kesimpulan berdasarkan informasi. Dari suatu informasi dapat diambil ide-ide, kemudian mengambil kesimpulan secara jelas dan logis. Pada penelitian ini, $\left(\mathrm{S}_{1}\right)$ tidak dapat menarik kesimpulan untuk semua soal, karena hanya terfokus pada penyelesaiannya saja. Sedangkan pada subjek yang lain dapat menarik kesimpulan dengan benar, hal tersebut menunjukan bahwa beberapa dari subjek terebut telah menggunakan kemampuan berpikir kritis. Hal ini sejalan dengan hasil penelitian Putri \& Istiyono (2018) yang menunjukkan bahwa terdapat kemampuan berpikir kritis siswa yang berbeda-beda.

Berdasarkan hasil temuan penelitian melalui tes tersebut, terdapat faktorfaktor penghambat dan faktor pendukung yang mendasari hasil jawaban kemampuan berpikir kritis siswa, di antaranya adalah sebagai berikut.

\section{Faktor Penghambat}

Guru kurang mampu dalam menstimulus siswa agar dapat berpikir 
kritis dengan memberikan soal-soal yang mengacu pada kemampuan berpikir kritis dan sesuai dengan kehidupan sehari-hari siswa. Sehingga siswa merasa kesulitan ketika dihadapkan soal cerita yang diharuskan untuk berpikir kritis. Dalam proses perhitungan dalam penyelesaian masalah terdapat beberapa siswa yang kurang tepat dalam mendapatkan hasil, dan tidak memahami konsep yang diminta dalam soal cerita. Selain itu, mereka tidak membiasakan untuk mengoreksi hasil jawabannya kembali.

\section{Faktor Pendukung}

Soal cerita yang bertaraf berpikir kritis khususnya pada muatan pelajaran matematika bagi kelas IV memang tidak lah mudah, dikarenakan pada kelas IV umumnya kurang dapat memahami konsep KPK atau FPB maupun pemfaktoran dari soal cerita tersebut. Tetapi siswa di SD Hang Tuah 10 Juanda mampu menyelesaikan hampir semua soal berpikir kritis meskipun tingkatan soalnya tinggi (HOTS) tetapi mereka tetap menyelesaikan semua soal tersebut dengan cukup baik.

\section{PENUTUP}

Berdasarkan hasil analisis data, dapat disimpulkan bahwa kemampuan berpikir kritis siswa dalam menyelesaikan soal cerita materi FPB dan KPK menunjukkan bahwa siswa belum mampu menemukan dan mengidentifikasi semua informasi dari masalah berdasarkan pada soal cerita (klarifikasi), siswa belum mampu dalam merumuskan atau menentukan pokok permasalahan yang dicari (asesmen), karena sebagian siswa dalam pengerjaan, siswa tidak menuliskan permasalahan tetapi langsung mencari jawaban dari konsep (FPB dan KPK) pada soal cerita, dalam menyelesaikan masalah dengan beragam alternatif penyelesaian berdasarkan konsep (strategi) hanya beberapa siswa saja yang mampu menyelesaikan masalah dengan beragam alternatif penyelesaian dengan benar, terdapat juga beberapa siswa yang mampu menyelesaikan masalah namun dengan penghitungan yang kurang tepat, dalam menarik kesimpulan (inferensi) sebagian besar siswa belum mampu dalam menarik kesimpulan dengan jelas dari hasil penyelidikan untuk semua soal, dan hanya sebagian kecil siswa yang mampu menarik kesimpulan dengan benar.

Dari hasil penelitian dan kesimpulan, maka dapat dianjurkan saran-saran sebagai berikut. (1) Bagi guru hendaknya perlu mengetahui seberapa jauh kemampuan berpikir kritis siswa untuk memaksimalkan agar pada pembelajaran yang akan datang bisa mendapatkan proses pembelajaran dengan hasil yang maksimal. Soal-soal yang diberikan kepada siswa hendaknya juga selaku diarahkan pada kemampuan berpikir kritis yang dimiliki untuk mengambil keputusan dan memecahkan masalah yang terkait dengan kehidupan sehari-hari. (2) Bagi siswa hendaknya terus mengasah cara berpikir kritisnya agar pada proses pembelajaran bisa mendapatkan hasil yang maksimal dan bisa menerapkan cara berpikir kritisnya untuk memecahkan masalah dalam kehidupan sehari-hari. (3) Bagi peneliti selanjutnya perlu dilakukan penelitian 
sejenis dengan sampel yang lebih banyak dan materi yang lebih bervariatif agar dapat memperkuat hasil penelitian.

\section{DAFTAR PUSTAKA}

Astiar, F. A., \& Satianingsih, R. (2020) Students' Speaking Skills Through Project Based Learning at Elementary Schools. Primary: Jurnal Pendidikan Guru Sekolah Dasar, 9(5), 672-679.

Ariani, S. (2018). Kemampuan Pemecahan Masalah Matematika Siswa pada Pembelajaran Matematika Menggunakan Strategi Abduktif-Deduktif di SMA Negeri 1 Insralaya Utara. Jurnal Elemen. Vol. 03. No.01. pp. 25-34

Hwa, S. P. (2018). Pedagogical change in mathematics learning: Harnessing the power of digital game-based learning. Journal of Educational Technology \& Society, 21(4), 259-276.

Jacob, S. M.,\& Sam, H. K. (2008). Measuring Critical Thinking in Problem Solving Through Online Discussion Forums in First Year University Mathematics. Proceeding of the International Multi Conference of Engineers and Computer Scientists in Hongkong 19-21 March 2008.

Karim, N. (2015). Kemampuan Berpikir Kritis Siswa dalam Pembelajaran Matematika dengan Menggunakan Model Jucama di Sekolah Menengah Pertama. EDU-MAT Jurnal Pendidikan Matematika. Vol. 03. No. 01. April 2015. pp. 92-104.

Kusmaharti, D. (2020). Efektivitas Online Learning terhadap Kemampuan Pemecahan Masalah
Matematika Mahasiswa. Journal of Medives: Journal of Mathematics Education IKIP Veteran Semarang, 4(2), 311-318.

Mira Azizah, J. S. (2018). Analisis Keterampilan Berpikir Kritis Siswa Sekolah Dasar Pada Pembelajaran Matematika Kurikulum 2013. Jurnal penelitian Pendidikan. Vol. 35. No. 01.

Nuraida, D. (2019). Peran Guru Dalam Mengembangkan Keterampilan Berpikir Kritis Siswa Dalam Proses Pembelajaran. Jurnal Teladan. Vol. 04. No.01.

O'Sullivan, M.K. \& Dallas, K.B. (2010). A Collaborative Approach to Implementing 21 Century Skills in a High School Senior Research Class. Education Libraries. Vol. 33. No.01. pp. 3-9.

Pradana, L. N. (2019). Visualisasi Spasial Abstrak Sebagai Penalaran Spasial Terkuat Siswa AUTIS. JIPMat, 4(2).

Putra, H. D. (2018). Kemampuan Pemecahan Masalah Matematis Siswa SMP pada Materi Bangun Ruang. Jurnal Ilmiah Pendidikan Matematika. Vol. 06. No.02. pp. $82-90$

Putri, S. F., \& Istiyono, E. (2018). The Development of Performance Assesment of Stem Based Critical Thinking Skill. International Journal of Environmental \& Science Education. Vol. 12. No. 05. pp. 1269-1281.

Rusminati, S. H., \& Sulistyawati, I. (2018). Implementasi lesson study menggunakan model think pair share dan pendekatan saintifik. Premiere Educandum: Jurnal Pendidikan Dasar dan Pembelajaran, 8(1), 88-97. 
Wardani, I. S. (2018). Penerapan Model Pembelajaran Inkuiri Untuk Melatih Kemampuan Berpikir Kritis Mahasiswa PGSD Unipa Surabaya. Pendas: Jurnal Ilmiah Pendidikan Dasar, 2(2), 170-178.

Wechsler, S. M., Saiz, C., Rivas, S. F., Vendramini, C. M. M., Almeida, L. S., Mundim, M. C., \& Franco, A. (2018). Creative and critical thinking: Independent or overlapping

components?. Thinking Skills and Creativity, 27, 114-122.

Windayana. (2007). Pembelajaran Matematika Realistik dalam Meningkatkan Berpikir Logis, Kreatif, dan Kritis serta Komunikasi Matematis Siswa Sekolah Dasar. Jurnal Pendidikan Dasar. Vol. 08. Hlm 35-40.

Yustitia, V. (2017). Profil kemampuan penalaran mahasiswa PGSD UNIPA Surabaya dalam pemecahan masalah matematika sekolah. Universitas PGRI Adi Buana Surabaya.

Yustitia, V., \& Amin, S. M. (2020, August). Mathematical literacy in pre-service elementary school teacher: A case study. In Journal of Physics: Conference Series (Vol. 1613, No. 1, p. 012054). IOP Publishing. 